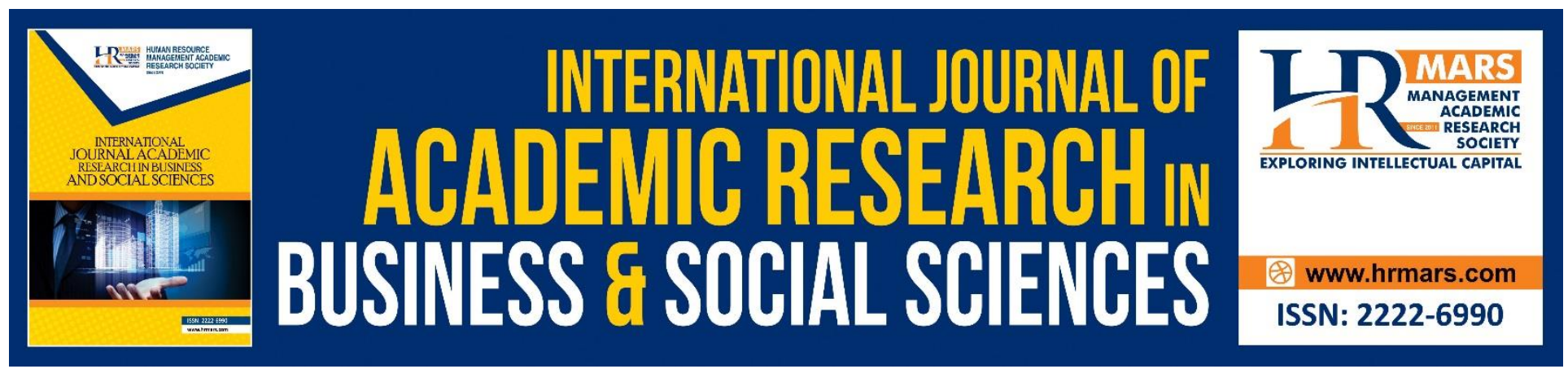

\title{
Issues in Information Management and Effects Towards Organisational Performance
}

Ahmad Affendi Mohd Nasir, Zaharudin Ibrahim, Norhayati Hussin, Hasnah Hashim, Saidatul Akmar Ismail, Mohd Ridwan Seman@Kamarulzaman, Shaharom TM Sulaiman

To Link this Article: http://dx.doi.org/10.6007/IJARBSS/v10-i11/8119

DOI:10.6007/IJARBSS/v10-i11/8119

Received: 01 September 2020, Revised: 30 September 2020, Accepted: 27 October 2020

Published Online: 24 November 2020

In-Text Citation: (Nasir, et. al., 2020)

To Cite this Article: Nasir, A. A. M., Ibrahim, Z., Hussin, N., Hashim, H., Ismail, S. A., Seman@Kamarulzaman, M.

R., \& Sulaiman, S. T. M. (2020). Issues in Information Management and Effects Towards Organisational

Performance. International Journal of Academic Research in Business and Social Sciences. 10(11), 527-536.

Copyright: (c) 2020 The Author(s)

Published by Human Resource Management Academic Research Society (www.hrmars.com)

This article is published under the Creative Commons Attribution (CC BY 4.0) license. Anyone may reproduce, distribute, translate and create derivative works of this article (for both commercial and non-commercial purposes), subject to full attribution to the original publication and authors. The full terms of this license may be seen

at: http://creativecommons.org/licences/by/4.0/legalcode

Vol. 10, No. 11, 2020, Pg. 527 - 536

http://hrmars.com/index.php/pages/detail/IJARBSS

JOURNAL HOMEPAGE

Full Terms \& Conditions of access and use can be found at http://hrmars.com/index.php/pages/detail/publication-ethics 


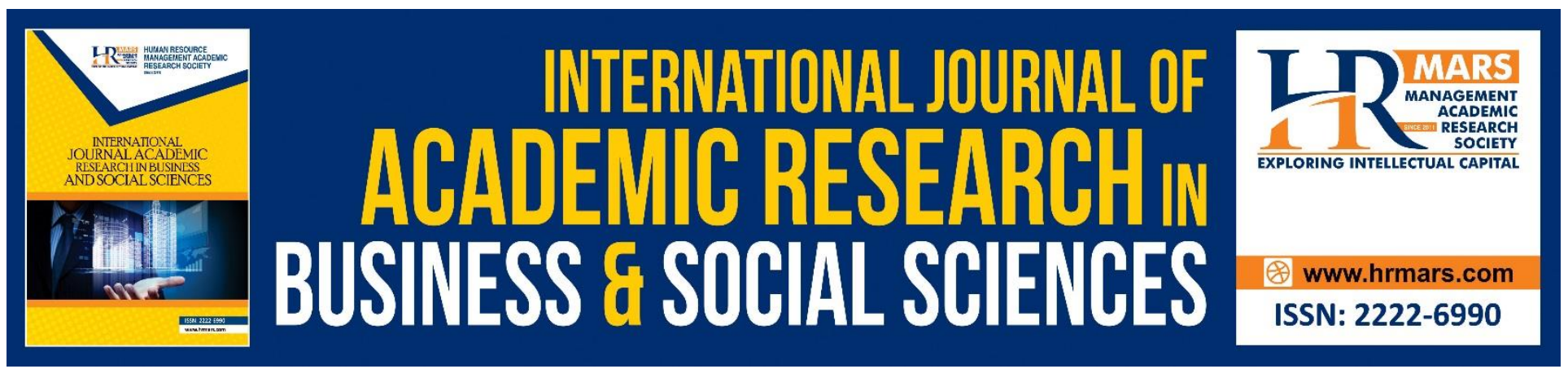

\title{
Issues in Information Management and Effects Towards Organisational Performance
}

\author{
Ahmad Affendi Mohd Nasir, Zaharudin Ibrahim, Norhayati Hussin, \\ Hasnah Hashim, Saidatul Akmar Ismail, Mohd Ridwan \\ Seman@Kamarulzaman, Shaharom TM Sulaiman
}

Faculty of Information Management, Universiti Teknologi MARA (UiTM) Selangor, Malaysia

\begin{abstract}
This study identifies the crucial issues in information management that affect organisational performance. The paper is based on the perusal reading of the authors based on several articles. The study identifies that the managing information as an important asset will help to change organisational operation by dominant the conception and development of information, reduction in operation cost, rising skillfulness and productiveness and precaution essential information. It also reassessment propose that organisations might start to create an information management scheme that has a modality of agree with the various systems into an ordinary system and this intent outcome in strategically benefit. The study was conducted based on several articles regarding the issues in information management. The lack of the latest research about the issues limits the findings for the sake of this writing. The recommendation and suggestion have been mention on this research for better study by the researcher on this area.
\end{abstract}

Keywords: Library and Information Management, Organisational Performance, Information Management Issue.

\section{Introduction}

As we know today, both electronic and physical information, generally is information. Information has cover all aspect of human lives and it is necessary to manage accordingly. Both individual and organization relies towards information to process and understand based on the beneficiary of their core business. Information management supports the centre activities of planning, analysis, action and, above all, learning and development. Information management capability can provide data and information to users with the appropriate levels of accuracy, timeliness, reliability, security, confidentiality, connectivity, and access and the ability to tailor these in response to changing business needs and goal (Mithas et al., 2011). The organisational structure should have capability to handling and process the information based on information life-cycle no matter in what kind of source or format such as data, electronic documents, audio, picture, video and physical document 
INTERNATIONAL JOURNAL OF ACADEMIC RESEARCH IN BUSINESS AND SOCIAL SCIENCES Vol. 10, No. 11, 2020, E-ISSN: 2222-6990 @ 2020 HRMARS

that can be deliver to multiple kind of channel which includes through smartphone as well as web interfaces.

Generally, management of the process and system that will create, acquire, organise, store, distribute, and use information is related with the definition of the information (Zaman, et al., 2018). Ridwan (2015) state information creation, acquisition, storage, analysis and use can supply the intellectual work which assist on development of the intelligent organisation. The essential players in information management must be the information users themselves, working in partnership with a cast that includes information specialists and information technologists. Information management must address the social and situational contexts of information use (Choo, 1998). Information Management might though as a set of process which support and make sure the organization's learning activities is balanced. Six distinct but related information management processes may be distinguished (Davenport \& Prusak, 1998):

- information needs;

- information acquisition;

- information organisation and storage;

- Information products and services;

- information distribution; and

- using information

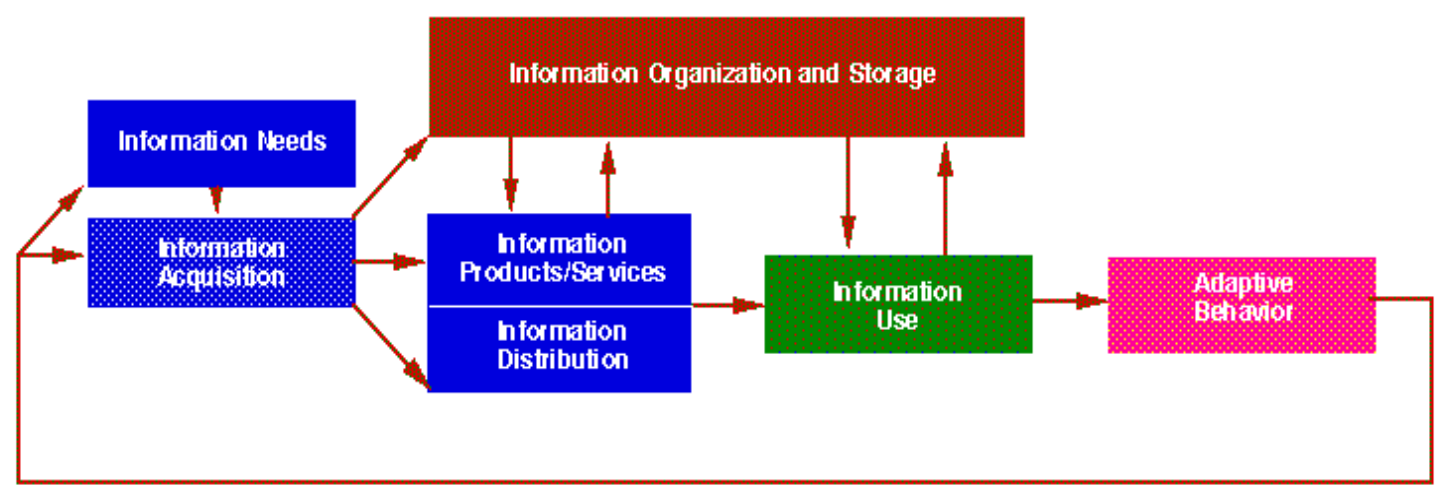

Figure 1: Information Management Cycles

\section{Literature Review}

Information management concerns the control over how information is created, acquired, organised, stored, distributed, and used as a means of promoting, efficient and effective information access, processing, and use by people and organisations (Detlor, 2010). The collection, organize as well as management of the information from one sources to others as well as arrangement of information from one or more people or employer called information management. This also includes people who involved direct and indirectly towards the information management. While, management is involved when the organisation have control over structure, processing as well as deliver of information. Even though there is no firm on the explanation of information management, but its vital to relies on the 
INTERNATIONAL JOURNAL OF ACADEMIC RESEARCH IN BUSINESS AND SOCIAL SCIENCES Vol. 10, No. 11, 2020, E-ISSN: 2222-6990 @ 2020 HRMARS

title is information management to achieve certain goals (Eroshkin, Kameneva, Kovkov, \& Sukhorukov, 2017).

The elements of information management has been widely used in various of industries such as social, technology, business as well as education. This term can be used to show the participation of information and knowledge that portray the involvement of civilization. Information show the critical issues that existed in the organisation where it is indicate on the business operation, productivity as well as performance outcomes. The information is an asset of any organisation, and it is a constant risk that may affect the capability of the organization if does not manage it properly. However, the right use and analysis the information result in increasing the productivity and performance of the organisation itself. Hussin, Hashim and Yu (2018) state the organization also should know to acquired and utilized information as well as their related resources strategically and they should understand strategic direction of their organization. The information is a valuable aspect that helps the organisation in improving its performance.

Organisational performance depends on the availability and practicability of information management in that organisation. Many people does not realize that the information management could assist organization to operate competitively and strategically as well as assist the employee to achieve targeted goal in organization (Fauziah et al, 2018). A successful organisation is an intelligent organisation. The intelligent organisation is an organisation act as a platform that utilized information, material and energy from the external environment, transforms these resources into knowledge, processes, and structures that produce goods or services which are then consumed in the environment. The intelligent organisation is, therefore, a learning organisation that is skilled at creating, acquiring, organising, and sharing knowledge, and at applying this information to design its behaviour. One of the critical issue about the workplace and organisation is how to make sure the productivity can growth and improved (Sul et al., 2015). By becoming an intelligent organisation which has systematic information management, it can boost and enhance profit growth.

Lately, there are several issues have been risen within information society and knowledge society on the information management and knowledge management to professional competencies, skills and attitudes towards digital technology and globalisation of information services. These concerns is vital to change the information management (Makori, 2009). Environment in changing the available information to pay information, information to knowledge, physical library to digital library and globalisation to technological innovation the emergence of Forth Industrial Revolution have sparked the issue in information management. The change in information creates resistance from some people. People and organisations alike always avoid on changes, whether beneficial or not. People will always avoid the changes even though it may lead towards new spectrum of knowledge or better utilization on people life. Moreover, some organization also resist change even though it will lead better performance, productivity as well as efficiency of the system. Therefore it is essential to identify the issues in information management to overcome it. 
INTERNATIONAL JOURNAL OF ACADEMIC RESEARCH IN BUSINESS AND SOCIAL SCIENCES Vol. 10, No. 11, 2020, E-ISSN: 2222-6990 @ 2020 HRMARS

\section{Issues in Information Management}

There are two main categories of issues affecting information management have been identified, namely, ethical issues and legal issues. One of the branch of philosophy that exploring and discovering of what is right or wrong is known as an ethics. People should behave ethically because in people's live has been set by ethical principles which ultimately related with moral values. Over the years, various scholar as well as philosopher have suggested many competing theories on ethical conduct. Some people belief that ethical behavior play a vital roles to lead greatest good for the greatest number of people. However, there are also some categories of people believe that ethics should be based on the religious values. While, law has been created by people to rules a society in maintaining social order, support justice as well as preventing any unethical behavior harm property and individual. A constitution, written or tacit may influence the formation of laws themselves, and the rights encoded therein. Law also could shape the country in term of politics, history, economic as well as society and community in various ways and become a medium to maintain the relation among people.

\section{Ethical Issue \\ Identity Theft}

Identity theft can be defined as a crime that involves one party to use the information for their gain. Identity theft can begin when the classified information falls in wrong hands thus permit the criminal use it to impostor the information, for example the criminal use to obtain account's bank or credit card information by using the victim's name. There are several example of identity theft in Malaysia such as cloning ATM, credit cards and debit cards, fraudulent transaction and other kind activities by criminal. According to Fam (2019), the top complaints Cybersecurity Malaysia (CSM) received within several years is identity theft where the personal information of Malaysia citizen has been stolen and used it for fraudulent transaction or other criminal activities. The identity thieves has multiple tricks and methods to make sure they obtain necessary information. This crime can be categories as silent crime. There were several ways that the information could be stolen such as phishing, hacking, dumpster diving, basic theft which is by stealing bank card or credit card, phishing which is phishing through a phone call, and spyware. With the growth of technology in this Forth Industrial Revolution, the way to steal the information will be different from times to times. A few weeks ago, the nation was shocked on the news of several people including Dato Sri (high-level title in Malaysia) has been scammed and lost thousands Ringgit Malaysia. The action played by the scammer was very convincing to some people plus the scammer has their full name, identification number and also emails address. The identity theft criminal will target the senior citizen and college students because of this kind of target easy to be deceived.

\section{Unauthorised Access to Computer Systems}

Unauthorized access represent on someone who gain authorized without authority permission to a website, program, services and other system by using other people accounts. For example, the unethical hacker kept find out the password and username of other people until they get access and enter those system, it is considered as unauthorized access. This kind of crime will occur when a user attempts to access on restricted areas on the system. In attempt to access on restricted areas, their request may be multiply denied by system and those action could possibly appear unauthorized 
access message. Fortunately, there are some system administration has setting their system with alert system to notify them when there are unauthorised people try to access restricted areas on the system. This precaution can assist them during investigation procedure in identified the hacker of the system. This kind of alert system will stop bad hacker to gain access on the system. Besides that, there are also some system that will lock an account or IP address of the hacker when they attempts multiple times in accessing those system.

\section{Lack of Decision-Making Skill}

The top management has authority to set organization policy and technical decision. There are organization state before make some decision, the top management will discuss the issues with subordinated and ask on their opinion.

However, in practices the top management rarely ask opinion from the subordinates. This is because the top management consider them much more knowledgeable and experienced in handling technical issues than subordinates, since top management are senior officers who have been promoted because of the high quality of their work. Technical issues are straight-forward issues. For example, guidelines and order by the organisation matters do not require opinions from subordinates. The final decision is based on precedent. However, in the case of administrative matters that affect work procedure, and the welfare of the employees, top management ask opinions and advice from subordinates.

\section{Lack of Planning}

Planning and organising the information is significant elements in the organization. The lack of proper planning and organising of what is necessary and why it is required in written forms and other kind of documentation by the organization has resulted the organization gain some not useful information. Strategically on information management by top management is crucial and important because the top management required to analysing the question that has been mention to avoid any trivial information and those kind of action is not relevant especially on the giant company.

\section{Unfair Distribution of Workload}

The management was said to be very strict in planning the allocation of the assessment workload to the subordinates. As a result, tasks are not assessed and completed on time and revenue is lost. Another issue on information management included a shortage of workforce, where the workloads are very high, but the top management refuses to hire more workers. This lead to information that cannot be managed properly since the employee does not have ample time to organise everything. Lack of recording system can lead to the issue of information management.

\section{Legal Issue}

Nowadays, people tend to share information without checking the truth. In this social media time, users more eager to share "fake" information on social media to get popularity. To control the spread of fake information and news, the government has introduced the Fake News Act 2018 to control the people from sharing the fake news. In an organisation, the spread of fake and false news and information is not a new thing. The employee prefers to not share the information with their 
colleague on the spot after receiving the information. The top management has to create a new environment to control the spreading of untruth information around the organisations. The organisation also must watch out on the confidentiality of the information before share it to the public. For example, the current news in Malaysia where a people shared the documents that have been classified as "top secret" and has been charged in the Court. Therefore, the employee must be aware of and manage the classification of the information.

\section{Effects towards Organisational Performance}

It is safe to write that the issues that had been written are normal in today organisations. The occurrence of issues on managing the information will cause the negativity to the organisational performance. Most of decision making from top management in the organisation is refer on inbuilt intellectual models and information base however those tacit knowledge can be enhanced and be verified by the formal decision-support mechanisms. It will cause information disasters, where the necessary information in making the decisions was irrelevant or unavailable and also ignored. For example, Nuclear scientists at Chernobyl, Ukraine failed to take account quickly enough of the information coming from their instrumentation to prevent accidents happening. To maintain the performance at a peak, the organisation must manage the information accordingly. The information received must be delivered to the right person at the right time.

\section{Suggestions and Recommendations}

Nowadays, the changing of current information environment required to posses a new skill and competencies within the organisation. The organisation much equipped with enough information technology-related competencies such as web design, internet searching, core hardware and software skills, evaluation of electronic information as well as the credibility of online information. Therefore, the organisation should provide the continuous traning to the information technology staff in improving their skill and competencies to welcoming the advancement of the digital technology (Makori, 2009). To support the implementation of information management, the organisation has to provide many infrastructures and facilities and come out with strategic directions towards information-based organisations. It is recommended that the employee should be involved in all phase of information management processes. The opinion and feedback from the employee should be taken in implementing the information-related activities. Through this, it will create the stronger organisation where the interaction is open from top management until bottom. This kind of direction will create healthy information sharing and collaboration environment in the organisation. This kind of direction also inline with the organisation philosophy which stressed on the role of the staff to take part on organisation and management activities. Each level of staff could contribute some ideas towards improvement of the organisation performance and operation.

Besides that, the organisation can also introduce a reward system either monetary or non-monetary in encourage the staff towards successfully managing the organisation especially in practicing the information management principle in organisation. The rewards can uplift the spirit of employe and it should be given based on considering the sharing information as one of criteria. The selection of competent leader by organisation who believe on the principle of information management and promoting its values and practices can influence other people to contribute it. Other than that, the 
INTERNATIONAL JOURNAL OF ACADEMIC RESEARCH IN BUSINESS AND SOCIAL SCIENCES Vol. 10, No. 11, 2020, E-ISSN: 2222-6990 @ 2020 HRMARS

appropriate and proper guidelines and procedure should be created and established as reference to the employee within the organisation. The guidelines and procedure are incremental to guide the organisation to achieve its vision and mission as well as direction to achieve more success in the future. The top management also required to allocated some budget for ongoing learning and training to its employee in educated them related with information management. Moreover, the employee should be trained not only on theory but technical field also should be trained either inhouse or outside organisation to make sure the employee possess the current skill and knowledge in developing their carreer in line with development of advance of technology. The organisation should also organise more activities like workshops, seminars, talks, colloquium and many more activities to share the knowledge that has the potential to generate value. This will also help to develop trust among the communities.

\section{Conclusions}

These issues have a direct bearing on the performance of an organisation. The information service environment is change over the time. Therefore, the organisation has to take some of the suggestion as there is a need to equip the employee about the importance of information management. The time has never seemed to be right to opt for this system there has always seemed to be such ongoing development that the "ideal" system must be just around the corner (Farik et al., 2015). Managing the information need to be done throughout the organisations as the marketplace and competition are rapidly change and updating knowledge and information which affected the overall performance of the organisation. After the initial part takes place, the continuous process of information has to be on the action to preserve the valuable data and information embedded in individual who is a part of the organisation system. Unrecorded information would be the loss for the organisation as a future reference and developing a better capable individual. After information management successfully applied in an organisation, the decision making quality will become increase. The benefit gain by information management will prosper the organisation. The organisation return on an investment will be higher. The organisation could have opportunities to develop more. By having the information management in the organisation, they may reduce the cost of the organisation. The organisation could increase the revenue of the organisation. After all,

The proper implementing of risk management can be a part of management of information because some component in using data and knowledge to identified any problem or hazards may be on horizon. When, the right way strategics of governance that related with information, it not only easier for people in all level but also towards organisation in achieving their goals as well as its objectives.

\section{Acknolwedgement}

This article is financially supported by:

Faculty of Information Management, UiTM Selangor, Malaysia.

\section{Corresponding Author}

Norhayati Hussin.

Faculty of Information Management, Universiti Teknologi MARA (UiTM) Selangor, Malaysia.

Email: yatihussin@uitm.edu.my 
INTERNATIONAL JOURNAL OF ACADEMIC RESEARCH IN BUSINESS AND SOCIAL SCIENCES

Vol. 10, No. 11, 2020, E-ISSN: 2222-6990 @ 2020 HRMARS

\section{References}

Choo, C. W. (1998). The Knowing Organisation: How an organisation use information to construct meaning, Create Knowledge and Make Decision Meaning. New York: Oxford University Press.

Davenport, T. H., \& Prusak, L. (1998). Working Knowledge: How Organisations Manage What They Know. Knowledge Creation 309. https://doi.org/10.1109/EMR.2003.1267012

Detlor, B. (2010). Information management. International Journal of Information Management, 30(2), 103-108. https://doi.org/10.1016/j.ijinfomgt.2009.12.001

Eroshkin, S. Y., Kameneva, N. A., Kovkov, D. V., \& Sukhorukov, A. I. (2017). Conceptual System in Modern Information Management. Procedia Computer Science, 103(October 2016), 609-612. https://doi.org/10.1016/j.procs.2017.01.079

Fam. (2019). CSM: Identity theft increasing in Malaysia mainly due to numerous data breaches. The Star, Retrieved October 2020, from: https://www.thestar.com.my/tech/technews/2019/04/16/ram-credit-information-to-work-with-cybersecurity-malaysia-to-preventidentity-theft/

Hussin, N., Hashim, H., \& Yu, H. (2018). Strategic Information Management (SIM) In Malaysian Organizations: An Investigation of its Antecedent. International Journal of Academic Research in Progressive Education and Development, 7(3), 291-304.

Makori, E. O. (2009). Contemporary issues in information management: A fresh look for information professionals. International Journal of Library and Information Science, 1(6), 82-91. Retrieved from http://www.academicjournals.org/ijlis

Mithas, S., Ramasubbu, N., and Sambamurthy, V. (2011). How information management capability influences firm performance. (2011). MIS Quarterly. 35, (1), 237-256. Research Collection School Of Information Systems. Available at: https://ink.library.smu.edu.sg/sis_research/219

Newman, I. (2001). Observations on relationships between initial professional education for software engineering and systems engineering-a case study. In Software Engineering Education and Training, 2001. Proceedings. 14th Conference on (pp. 172-181). https://doi.org/10.1109/CSEE.2001.913840 1470854

Ridwan, S. M. (2015). Application of Information and Communication Technology in Management of Information in Local Government Areas of Nigeria. International Journal of Advancements in Research \& Technology, Volume 4, Issue 1. ISSN 2278-7763.

Salleh, F., Md.Radzi, R., Hussin, N., Ahmad, A. R., \& Ibrahim, Z. (2018). New Information Management Dimension in Blockchain. International Journal of Academic Research in Business and Social Sciences, 8(12), 1382-1391.

Sul, S., Wan, K., Shahibi, M. S., Hussin, N., Jamaludin, A., \& Amin, Z. M. (2015). Factors of Knowledge Workers retention in the Organisation. International Journal of Innovative Research in Computer Science \& Technology (IJIRCST), 3(2). Retrieved March 2018, from https://www.scranton.edu/alumni/pdf/TrustedID_Complete\%20Insight\%20into\%20Identity \%20Theft\%20in\%20America-1.pdf

Yatin, S. F. M., Ramli, A. A. M., Shuhaimi, H., Hashim, H., Dollah, W. A. K. W., Zaini, M. K., \& Kadir, M. R. A. (2015). Electronic Document Management System: Malaysian Experience. Australian Journal of Basic and Applied Sciences, 9(3), 82-89.

Zaman, N. A. B., Saad, N. S., Ahmad, M., \& Hussin, N. (2018). Information Management: Elements and 
INTERNATIONAL JOURNAL OF ACADEMIC RESEARCH IN BUSINESS AND SOCIAL SCIENCES Vol. 10, No. 11, 2020, E-ISSN: 2222-6990 @ 2020 HRMARS

Relations in Organisation. International Journal of Academic Research in Business and Social Sciences, 8(12), 1436-1443. 